\title{
AN AGING POPULATION: A COMPETITIVE ADVANTAGE FOR COMPANIES
}

\author{
- Petra Barešová, Monika Horáková, Tomás Urbánek
}

\begin{abstract}
This article focuses on one of the most currentlydiscussed topics, the ageing population. Population aging can be discussed from different perspectives, exploring various challenges associated with it. The authors examined marketing communications from the point of view of a target group, over age 55. The main objective of this study was to find out which marketing communication tools those over age 55 prefer, including selected aspects of printed advertising. At the same time, it was examined whether there is a different gender perspective on this issue. To find out answers to the main question of this study, we conducted quantitative research by using a questionnaire survey among the population over age 55 living in the Czech Republic (Zlín Region). The results of this study were compared with the results of a previous study conducted in 2014, focusing on the marketing communication tools targeted at the 55+ group from the point of view of companies.

The research results have shown that the target groups' most effective (preferred) marketing communication tools are printed materials (leaflets and catalogues), sales promotions, competitions, club memberships, gifts, fairs, markets and fairs, and last but not least, newspapers and magazines. Based on the results, it can be said that these tools, in comparison with others, contain sufficient information that the customer can read and think about, save, and eventually return to them. At the same time, they are tools that bring a certain benefit or advantage to the customer, which can then be verified in person. If the results are compared from a gender perspective, different preferences were revealed in the selection of marketing communication tools. There were also different views on some selected aspects of printed materials. These findings can be implemented by companies and organizations in their marketing campaigns, allowing them to better reach the target group of people over age 55. Focusing on new markets, including a new, forward-looking target group, can give companies a competitive edge.
\end{abstract}

Keywords: population ageing, consumer behaviour, marketing communications, effectiveness of marketing communications, competitive advantage

JEL Classification: J11, M31

\section{INTRODUCTION}

Demographic predictions clearly indicate that the population is ageing. Based on these predictions, the number of people over age 55 will increase significantly in the forthcoming years, and not only in the Czech Republic. Therefore, it is undeniable that this age group will significantly influence not only the health system, but also running of the state system, affecting the economy and individual companies and organizations. Dvořáková (2007) notesthat the older generations, as customers, will significantly influence the economy. In other words, this age group play an important role in 
the market (Accolla \& Garini, 2017). For this reason, Tréguer (2002) supports the idea of focusing, among other things, on the development of new marketing approaches and strategies for this age group, both scientifically and practically. Kohlbacher \& Herstatt (2011) classify older people as a growing silver market. For companies and organizations, it is therefore extremely important to have as much information as possible about this target group and understand their needs and expectations. This valuable knowledge can provide a competitive advantage for companies from various industries.

To have an effective communication with this target group, it is important not only to identify what kind of products the people want, but also what marketing communication tools they prefer. High credulity, loneliness, and a need for societal belonging affect the purchasing decisions of this target group, which companies often abuse only to maximize profits. This behaviour often leads some customers to distrust and lose interest in buying unknown products and services. Companies and organizations should therefore emphasize the effective, but not forget the ethical aspect of marketing communication (Wolf, 2017). Today, companies cannot ignore the enormous influence of modern technologies and the Internet itself.

For these reasons, this article focuses on the identification of effective (preferred) marketing communication tools for the target group 55+, including the point of view from the gender perspective. Supplementary fields of research were traditional tools such as leaflets,catalogues and the Internet. These results and knowledge can be implemented by companies and organizations in their marketing communication campaigns to better reach the target group over age 55 .

\section{LITERATURE REVIEW}

\subsection{Marketing Communication}

The definition of marketing communication has a number of forms. Nevertheless, most authors agree that marketing communication is part of the so-called marketing mix in any concept (e.g., Karlíček et al., 2016; Vysekalová, 2000; Kotler, 2007; Fill, 2013) and is influenced by its other components. Karlíček et al. (2016) state that the primary goal of marketing communication is to inform and persuade the target audience in order to achieve certain company goals.

Choosing the right product and understanding the needs of the target group is not enough. It is also important to prepare the right ways to inform the target group about products and services and to persuade them and generate interest in purchasing. For this reason, it is necessary to set up a marketing plan with predefined goals. The fulfillment of marketing goals is influenced by a number of factors, including correctly implemented situational analysis (understanding of market and target group), correctly designed marketing messages, properly chosen marketing communication tools, well-defined goals, and steps to achieve them.

The new understanding of marketing and its development gives rise to a number of new marketing communication concepts. This article trends towards the integrated marketing communication (IMC), which is considered a new trend century (Luck \& Moffatt, 2009). Many companies very quickly implemented this concept in their strategies (Kitchen, 2015). The IMC can be explained as a "concept whereby the company carefully integrates and coordinates the volume of its com- 
munication channels to bring a clear, consistent and convincing message to the organization and its products" (Kotler, 2007). In other words, according to Lee \& Park (2007), it is a systematic integration of various communication tools and channels, but also a coordination of all messages to create a unified communication mix of the company. Schultz (1993) sees the added value of the integrated marketing communication in its entirety and a comprehensive plan of combining individual marketing mix tools that ensure clarity, consistency, and coherence, but above all, having a greater and positive impact of marketing communication on company results. However, Patti, Hartley, van Dessel, \& Baack (2015) are of the opinion that even in the integrated marketing communication, there is still something to improve.

The marketing communication process is divided into several phases, each phase having its significant role in the success of the marketing campaign. According to Prikrylová (2010), the communication process can be explained as the process of transmitting the message from the company (sender of the message) to the consumer (recipient of the message). Part of the communication process that takes place between the company and the target group (consumer) is: marketing communication, creative rendering, and marketing communication tools. All these components are disturbed by communication noise.

The last part of the communication process is an appropriate choice of marketing communication tools (Karlíček, 2016; Vysekalová, 2000; Přikrylová, 2012). The right selection of marketing communication tools can lead to the better and competitive position of company in the market. There is no exception that each marketing communication tool has own function and they are chosen for a particular marketing message (Karlíček, 2016). However, Fill (2013) also emphasizes that each marketing communication tool has a different role and can play a different role in marketing communications.

There is a large number of different categorizations of marketing communication tools. To analyse marketing communication tools better, the ATL-BTL-TTL categorization is used (Raiko, Tseytlin \& Kyrylenko, 2017). However, categorization of marketing communication tools described by Karlíček (2016) is clearly and well arranged, therefore, it coresponds to the purpose of this article. The most transparent and most comprehensive breakdown (Figure 1) is used by Karlíček et al. (2016). Karlíček et al. (2016) include in the marketing communication tools: the following personal sales, advertising, direct marketing, sales promotion, and public relations, but also event marketing and sponsorship. All of these tools can also be online. The dominant marketing tools still include TV commercials and flyers. Both tools are unaddressed and provided broad reach for customers. While TV advertising builds the image of the brand through emotional reaction, the advertising flyers build a rational link through a discount advantage (Malčikovová, 2012). Compared to traditional communication tools, a sharp rise in the use of a marketing tool such as the Internet can be seen in recent years (McGaughey, \& Mason, 1998). The authors, such as Papasolomou and Melanthiou (2012), see an essential element in the implementation of Internet advertising in the company's marketing processes. In particular, they emphasize the role of social networks and the Internet. The authors in their research (Shen et al., 2016) have pointed out a higher effectiveness in using interactive social advertising. Lamberton \& Stephen (2016) point out the rise in social, digital, and mobile marketing. Fill (2013) adds that word-of-mounth (WOM) is not the actual passing of experience and recommendations, rather it is the most effective form of a marketing communica- 
tion. Shirkhodaie \& Rastgoo-deylami (2016) also take the view that WOM is far more effective than any marketing communication tools that WOM should complement. At the same time, each marketing communication tool has a different function; it is suitable for typical messages and for different target groups. However, they can be mixed together and complement each other to reach particular aims of marketing communication.

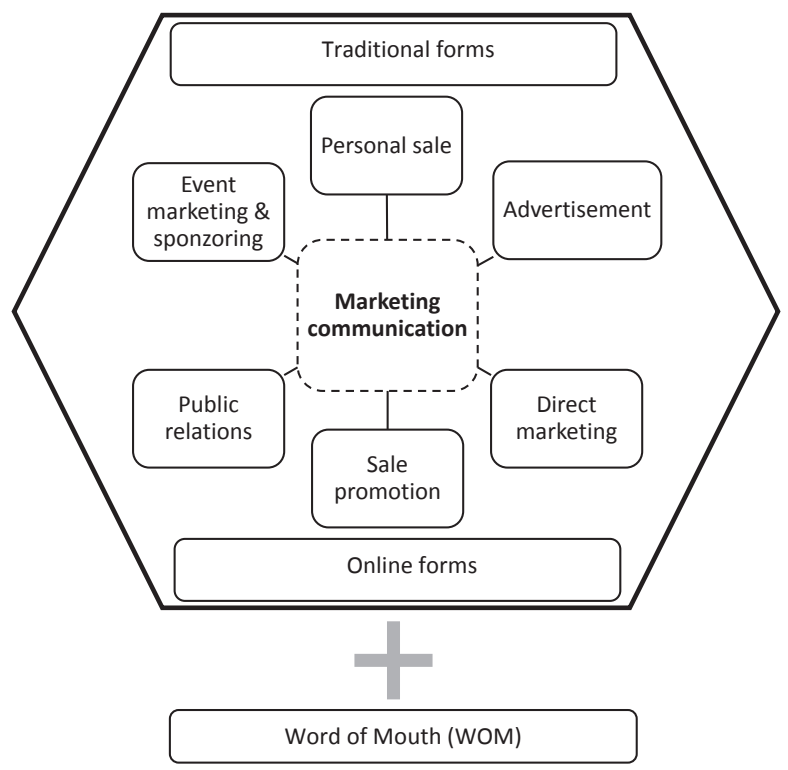

Fig. 1 - Tools of Marketing Communication. Source: Karliček (2016), Fill (2013)

\subsection{Elderly People - An Attractive Target Group in the Future}

To understand the target group of people over 55 years old, it was necessary to find out their characteristics. The literary research was mainly focused on the age as perceived by society, the positives of this period of life, and the economic-demographic indicators associated with the age. According to Becka (1996), a demographic change and the associated new trends lead to the creation of a new market and new opportunities for a number of sectors and industries, also to find a new way for companies to get a new competitive ability. A number of authors (e.g. Long, 1998; Ahmad, 2002) agree that for businesses the 55+ target group, may be interesting in terms of their number and purchasing power, and also in terms of the diversity of this group. According to Dvořáková (2007), the older generation is talked about as future customers who will show trends in the market and will significantly affect the economy. It means that this age group will belong to the market segments, which will play an important role in the market. Current studies highlight that many marketers do not focus on this target group as their key customers. For this reason, it is important to help them understand this group and identify their preferences of marketing communication tools to attract this target group. 
The definition of age is not unambiguous, especially since ageing does not have a clearly defined age limit. The upper extent is limited by death, but the beginning of ageing is individual and depends on individual attitudes during their whole lives (Birkett, Carmichael, \& Duberley, 2017). Many authors agree that each period of human life brings its specific changes. However, there is no doubt that there is a number of visible changes in old age. According to Mühlpachr (2004), the changes are physiological and psychological, as well as social. Unfortunately, ageing is generally perceived as a period associated with health and social problems, as confirmed by most studies. Some authors (e.g. Dychtwald, 1999; Polizzi \& Millikin, 2002) also report in their publications negative stereotypes that are generally known in society and which negatively affect the view of people for this part of life and thus raise concerns about the old age. These stereotypes and myths, according to Sokačová et al. (2005), may result in the underutilized potential of older people in society. This is why many authors try to point out the positives and raise this period of life positively. There is an effort to positively promote old age as a period of life when people have time for activities that cannot be realized during the productive age. For example, Malíková (2011) tries to point out the fact that old age brings new opportunities and chances. As stated in Sak's work (2012), the Czech population sees the contribution of ageing in terms of leisure time, space for activities and hobbies, time for relaxation and rest, space for family and grandchildren, and the possibility of changing the lifestyle. The individual positive benefits of age are shown in the following Fig. 2.

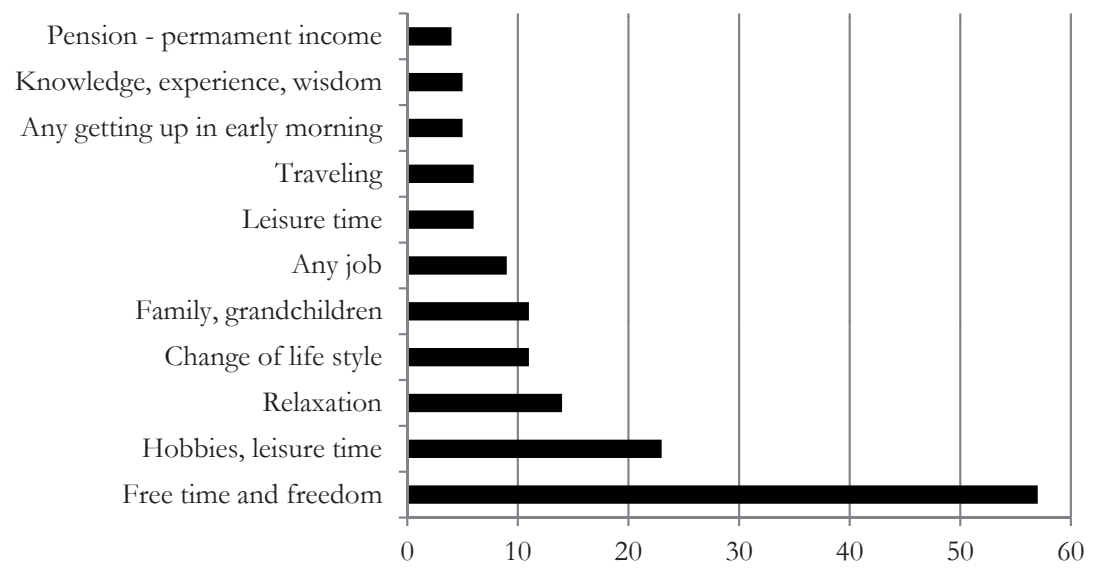

Fig. 2 - Positive side of retirement. Source: Sak (2012)

As shown in Tab. 1, in the Czech Republic, there are demographic changes and an increase in the population of senior citizens. People aged 65+ in the Czech Republic accounted for $17.8 \%$ of the population in 2014 compared to the total population. From the chart below (Figure 3), the structure of the age group over 55 can be read. The largest number was the age group of the population aged 65-69 (Czech Statistical Office, 2016a). The latest version of the national gender statistics from 2016 indicates that the proportion of people aged 60+ in the Czech Republic accounts for $25 \%$ of the total population. From this quarter, the proportion of women in the age group of $60+$ accounts for 57\% and 43\% for the proportion of men (Czech Statistical Office, 2016b). 
The region's statistics included data on the oldest living population, with the highest number of the oldest population in the Czech Republic being the Královehradecký Region (19\%), the Plzeň Region (18.4\%), and the Zlín Region (18.3\%) (Benešová \& Dědič, 2015). Nevertheless, in the future, the prediction shows that the group of persons over the age of 65 in the future (from 2051) will account for over 30\% of the population living in the Czech Republic (Němečková \& Štyglerová, 2014).

Tab. 1 - Age structure of people over 55 years old in the Czech Republic. Source: Czech Statistical Office (2016b)

\begin{tabular}{|l|l|}
\hline \multicolumn{2}{|l|}{ Age structure of people over 55 years old } \\
\hline $55-64$ & 1407469 \\
\hline $65-74$ & 1153094 \\
\hline $75-84$ & 545213 \\
\hline $85+$ & 182099 \\
\hline
\end{tabular}

The seniors can also be seen as consumers who enter the market for products and services to meet their needs. This purchase is limited by their budget constraints and income (= consumer income) (Mankiw and Taylor, 2014). The limit for the purchase of goods and services for the elderly as a consumer represents the sum of the old-age pension and other social transfers and income. The following Tab. 1 shows the composition of the number of persons receiving the old-age pension according to the amount. However, official statistics on the average amount of the pension do not always correspond to reality. If we compare the amount of old-age pensions with the subsistence minimum, which was CZK 3,410 in 2014 (the same as in 2017), almost 1.5\% of people receiving retirement pensions live at the subsistence level (MPSV, 2013).

From Tab. 2, it is clear that more than $80 \%$ of women received a monthly pension of more than CZK 10,000, while $80 \%$ of men recieved more than CZK 8,000. An overwhelming majority of women received a pension in the range of CZK $10-13,000$ compared to men, when more than half of them have a pension of CZK 8 - 11,000. There is a visible financial mismatch between the two sexes. This inconsistency in statistics can be caused by various factors such as the way pensions are calculated, life expectancy, access to health care in the city and the countryside, etc. Despite these facts, companies should count on this economic indicator, especially when planning their product portfolio for this age group. (Czech Statistical Office, 2014)

Tab. 2 - Old-age pension in the Czech Republic. Source: Czech Statistical Office, 2014

\begin{tabular}{|l|c|c|c|c|}
\hline $\begin{array}{l}\text { Old age pension in CZK } \\
\text { (per a month) }\end{array}$ & $\begin{array}{c}\text { Number of old } \\
\text { people (women) }\end{array}$ & $\%$ & $\begin{array}{c}\text { Number of old } \\
\text { people (men) }\end{array}$ & $\%$ \\
\hline up to 3999 & 3,793 & 0,5 & 7,906 & 0,9 \\
\hline $4000-4999$ & 2,204 & 0,3 & 6,943 & 0.7 \\
\hline $5000-5999$ & 3,038 & 0,4 & 11,340 & 1,2 \\
\hline $6000-6999$ & 4,598 & 0,6 & 22,431 & 2,4 \\
\hline $7000-7999$ & 9,026 & 1,1 & 61,149 & 6,6 \\
\hline $8000-8999$ & 19,698 & 2,5 & 154,542 & 16,7 \\
\hline
\end{tabular}




\begin{tabular}{|l|c|c|c|c|}
\hline $9000-9999$ & 52,268 & 6,6 & 237,358 & 25,6 \\
\hline $10000-10999$ & 129.206 & 16,2 & 180,651 & 19,5 \\
\hline $11000-11999$ & 163,982 & 20,6 & 117,948 & 12,7 \\
\hline $12000-12999$ & 152,432 & 19,1 & 69,929 & 7,5 \\
\hline $13000-13999$ & 122,687 & 15,4 & 31,451 & 3,4 \\
\hline $14000-14999$ & 73,076 & 9,2 & 11,283 & 1,2 \\
\hline $15000-15999$ & 34,570 & 4,3 & 5,259 & 0,6 \\
\hline $16000-16999$ & 9,371 & 1,2 & 3,007 & 0,3 \\
\hline $17000-17999$ & 5,437 & 0,7 & 1,809 & 0,2 \\
\hline 18000 above & 11,452 & 1,4 & 3,406 & 0,4 \\
\hline
\end{tabular}

From the facts above, it is clear that the growing population aged over 55 is a trend that will continue in the next years. The current question is how society, companies, and goverment will deal with this challange. Czech companies should refrain from negative perspectives on this target group, focus on their positive aspects, and look for challenges that will guarantee them a competitive advantage.

\section{AIM AND METHODOLOGY}

The main goal of this work was to find out the preferences of marketing communication tools in the target group of people over 55 years old. The data obtained was analyzed in more detail and statistically tested also from a gender perspective. The hypotheses in this article were drawn up in connection with the previous results obtained by Barešová \& Staňková (2017). Their research has revealed preferences of people age 55+ regarding leisure activities. Additional questions focused on how much time people 55+ spend on reading leaflets, how they use the Internet, and what selected aspects of printed advertising they prefer. Subsequently, this data was also compared with the results from a previous study published by Barešová \& Staňková (2015). This study investigated the attitudes of selected Czech companies towards marketing communication focused on this target group 55+.

\subsection{Research data - people age $55+$}

The survey was conducted in March - May 2016. The primary data was obtained through a quantitative survey via an online and printed questionnaire. Both methods of collecting data were mainly used to get a relevant number of respondents. It is generally known that electronic questionnaires have a low return. This research tool was distributed electronically and in printed form to participants of University of Third Age at Tomas Bata University in Zlín. The questionnaire was also distributed in senior clubs and centers in the Zlín region. Therefore, it can be said that they spend their time actively. The sampling of respondents can be characterized as follows:

- Persons over 55;

- Active leisure activities;

- No limits in gender, place of residence, and socio-economic status.

The respondents answered two main questions in the questionnaire: 
The first area was focused on socio-demographic characteristics. These identifying characteristics included: gender; age; education; current and previous job positions; family status; number of children and grandchildren; housing. For the purpose of this article, only was used gender characterisation. Others socio-demographic characteristics will be used for further study and publications.

The second area was marketing communication issues (which marketing communication tools they prefer, which aspects of the printed advertisement they prefer - colour, type and font size, advertisers). The questions related to the aspects of printed advertisement were displayed in the graphic form. There were prepared questions with several variants of answers. Another question was related to time that they spend on reading leaflets. One more question related to marketing communication was the use of modern technologies, namely working on the Internet. The respondents were asked how often they use the Internet and what kind of activities they are doing there.

Before the questionnaire itself, the following research questions and hypotheses were set. The data obtained was then evaluated by preference analysis. In order to compare gender data, the selected data was statistically verified using the Pearson's Chi-squared test statistic at a significance level $\alpha=5 \%$. By using this method, the hypotheses H0 (1-7) were rejected / not rejected (Hendl and Remr, 2017).

RQ1: Which marketing communication tools do the respondents (people over 55 years old living in the Czech Republic) prefer most and consider as most effective?

$\mathrm{HO}_{(1)}$ : Women prefer the same marketing communication tools as men.

RQ2: What kind of selected aspects of printed advertising (background color, font type and font size, people present) are preferred by respondents most?

$\mathrm{HO}_{(2)}$ : Women have the same preferences when choosing the background colour of printed advertising as men.

$\mathrm{HO}_{(3)}$ : Women have the same preferences when selecting the font type of printed advertising as men.

$\mathrm{HO}_{(4)}$ : Women have the same preference for selecting the font size of printed ads as men.

$\mathrm{HO}_{(5)}$ : Women have the same preferences in the selection of people (actors) in printed advertising as men.

RQ3: How much time a week do the respondents spend on reading leaflets?

$\mathrm{HO}_{(6)}$ : Women spend the same amount of time reading the as men.

RQ4: Do the respondents use the Internet? What kind of activities do they do?

$\mathrm{HO}_{(7)}$ : Women spend the same amount of time on the Internet as men.

As a result of this research focused on people 55+, the findings were compared with the results of the previous research conducted in 2014 by the authors Barešová \& Staňková (2015). The respondents were companies in the Czech Republic and the aim of the study was to find out whether companies in the Czech Republic are targeting people over 55 years old and, if so, what marketing communication tools they use. 


\section{DATA ANALYSIS AND RESEARCH RESULTS}

The primary research on the target group of respondents over 55 years old were evaluated using MS Excel. The data analyzed was were also statistically verified using Software R.

\subsection{Fundamental characteristics - the age group of $55+$}

Based on socio-demographic characteristics, a group of respondents can be described as follows. The survey was attended by 497 respondents, there 406 women $(81.7 \%)$ and 91 men (18.3\%). The largest age group was represented by people from 65 to 69 years old $(36.1 \%)$, followed by people from the age group 60-64 (30.6\%). From education perspective, most respondents had secondary education $(62.5 \%)$ or graduated at from university $(31.9 \%)$. Nearly half of respondents previously worked in the state sector $(41.7 \%)$, and more than half of them currently receive a retirement pension without a secondary income. Almost $87 \%$ receive a retirement pension higher than 10,000 CZK. More than half of them live in an apartment (55.6\%) and only 1.4\% of respondents live in retirement homes. Almost 63\% of respondents said they live with their wife/husband. There are $29.2 \%$ of the respondents without a wife/husband or partner. There are $11.1 \%$ of respondents being married, $16.7 \%$ divorced, and $27.8 \%$ of respondents are widoved. More than half of the respondents have two children and $68.1 \%$ of them have grandchildren. Almost every fifth respondent takes care of a domestic animal, i.e. $18.1 \%$ of all respondents.

\subsection{Results of primary research - age group of $55+$}

The following Tab. 3 shows the final results of the research including the results of hypotheses.

Tab. 3 - Results of primary research. Source: own source

\begin{tabular}{|c|c|c|c|c|}
\hline & $\mathrm{RQ} / \mathrm{H}$ & Field of research & $\begin{array}{l}\text { Results } \\
\text { (p-value) }\end{array}$ & Assessment \\
\hline \multirow{2}{*}{ 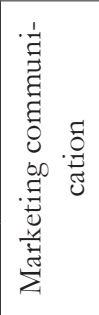 } & RQ1 & $\begin{array}{l}\text { Which marketing communication } \\
\text { tools do the respondents (people } \\
\text { over } 55 \text { years old living in the } \\
\text { Czech Republic) prefer most and } \\
\text { consider as most effective? }\end{array}$ & $\mathrm{x}$ & $\begin{array}{l}\text { flyers; sales promo- } \\
\text { tion; trade fair, fairs, } \\
\text { markets; articles in } \\
\text { newspapers and maga- } \\
\text { zines; }\end{array}$ \\
\hline & $\mathrm{HO}_{(1)}$ & $\begin{array}{l}\text { Women prefer the same marketing } \\
\text { communication tools as men. }\end{array}$ & $2.755 e-05$ & rejected \\
\hline
\end{tabular}




\begin{tabular}{|c|c|c|c|c|}
\hline \multirow{5}{*}{ 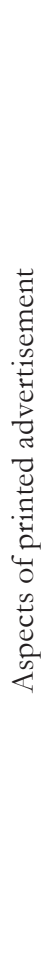 } & RQ2 & $\begin{array}{l}\text { What kind of selected aspects of } \\
\text { printed advertising (background } \\
\text { color, font type and font size, } \\
\text { people present) are preferred by } \\
\text { respondents most? }\end{array}$ & $\mathrm{x}$ & $\begin{array}{l}\text { Colour (light green); } \\
\text { font (sans-serif); font } \\
\text { size ( } 30 \mathrm{pt}+) \text {; people } \\
\text { in advertisement } \\
\text { (experts) }\end{array}$ \\
\hline & $\mathrm{H}_{(2)}$ & $\begin{array}{l}\text { Women have the same preferences } \\
\text { when choosing the background } \\
\text { colour of printed advertising as } \\
\text { men. }\end{array}$ & 0.001106 & rejected \\
\hline & $\mathrm{H} 0_{(3)}$ & $\begin{array}{l}\text { Women have the same preferences } \\
\text { when selecting the font type of } \\
\text { printed advertising as men. }\end{array}$ & 0.2231 & not rejected \\
\hline & $\mathrm{H} 0_{(4)}$ & $\begin{array}{l}\text { Women have the same prefer- } \\
\text { ence for selecting the font size of } \\
\text { printed ads as men. }\end{array}$ & 0.1991 & not rejected \\
\hline & $\mathrm{H} 0_{(5)}$ & $\begin{array}{l}\text { Women have the same preferences } \\
\text { in the selection of people (actors) } \\
\text { in printed advertising as men. }\end{array}$ & 0.2873 & not rejected \\
\hline \multirow{2}{*}{ 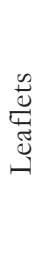 } & RQ3 & $\begin{array}{l}\text { How much time a week do the } \\
\text { respondents spend on reading } \\
\text { leaflets? }\end{array}$ & $\mathrm{x}$ & 15 - 30 minutes \\
\hline & $\mathrm{H}_{(6)}$ & $\begin{array}{l}\text { Women spend the same amount of } \\
\text { time reading the leaflets as men. }\end{array}$ & 0.008785 & rejected \\
\hline \multirow[t]{2}{*}{ 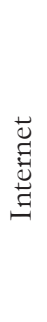 } & RQ4 & $\begin{array}{l}\text { Do the respondents use the In- } \\
\text { ternet? What kind of activities do } \\
\text { they do? }\end{array}$ & $\mathrm{x}$ & $\begin{array}{l}\text { Chating with friends; } \\
\text { looking for informa- } \\
\text { tion about products } \\
\text { and services, shop- } \\
\text { ping; }\end{array}$ \\
\hline & $\mathrm{H} 0_{(7)}$ & $\begin{array}{l}\text { Women spend the same amount of } \\
\text { time on the Internet as men. }\end{array}$ & 0.08326 & not reject \\
\hline
\end{tabular}

The most preferable marketing communication tools are flyers and catalogues; sales promotion (these include preferential prices, competitions, club membership, etc.); fairs, markets and fairs; websites; articles in newspapers and magazines. The complete results are illustrated in the following graph in Fig. 4 below. 


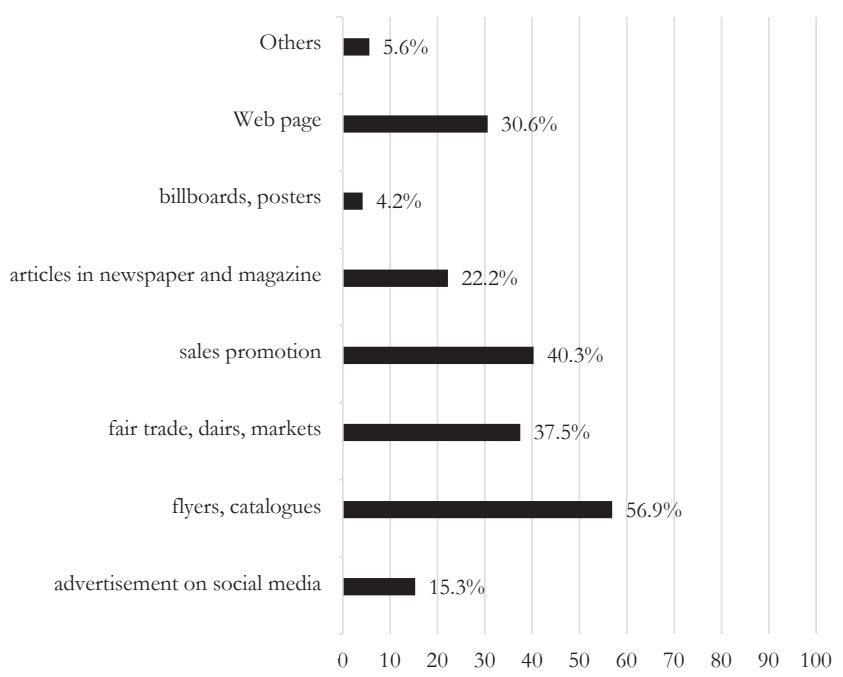

Fig.4 - Preference of marketing communication tools. Source: own research

The statistical verification of a gender perception of tools has revealed a different structure of preferences. Women's most favourite marketing communication tools are leaflets and catalogues, sales promotions, prizes, club membership, gifts to buy, websites and fairs, markets and fairs. While men most preferred leaflets and catalogues, internet advertising and fairs, markets and fairs.

The research question RQ2 tested four aspects of printed advertising in detail (background colour, font type, font size, and an outgoing person). The most preferred colorus were light green, yellow, and white. From the gender analysis perspective, significant differences were statistically proven. Women preferred light green, yellow, and light blue. The men tended to prefer a pale green, dark blue, white, and yellow background colour. For the remaining test hypotheses on font type and font size in the advertising, the significant statistical differences have not been demonstrated for women and men. The most commonly used type of font was the sans-serif font. On the other hand, the unsuitable font for the advertisement was the modern typeface. The other tested aspect of the printed advertising was the font size. Both genders preferred the greatest possible font. In the text format, the font size 30 was preferred for titles, and the size of the actual text content was 20. The last aspect tested was the image of people who are in the advertisement. Both genders preferred experts in advertisements, then young people, elderly people, and very few respondents appealed to popular figures.

The research question RQ3 focused on the time spent on reading leaflets. There was a statistically proven difference between women and men. Women mostly spent only 15 minutes reading leaflets. On the other hand, men spent more time on reading leaflets, from 15 to 30 minutes reading longer.

By analyzing the research question RQ4 which concerns the Internet use, there was no statistically significant difference between the genders. Men and women most often use the Internet 
daily. They use this tool to communicate with friends and family, search for product and service information, and a surprisingly high percentage of respondents do online shopping.

\subsection{Secondary research study - Firms and organizations}

Based on the results from this study, it is necessary to understand and analyse marketing communication from the companies perspective and get complete view on this topic. For this reason, there is a short summarization of a previous case study published by Barešová \& Staňková (2015) used. 54 small and medium-sized companies and organizations took part in their research. The vast majority of respondents were associations and limited liability companies. In particular, this study looked at whether the companies and organizations create special marketing campaigns targeting the group of people over 55 years old. If so, which kinds of marketing communication tools they use to target this group.

Their results have shown that the companies only minimally pay attention to this target group $55+$ in terms of promotion. If they somehow modified the marketing campaign for customers $55+$, it was only for the following marketing communication tools:

- Outdoor advertising - in the form of posters and billboards;

- Banner campaigns on websites;

- Different forms of printed advertising - flyers and catalogues.

On the other hand, radio, sponsorship, and PR activities are used very rarely by companies (Barešová \& Staňková, 2015).

\section{DISCUSSION}

Demographic changes and population ageing lead to reflection on the current situation and to discussions about further developments so the each countris and business are able to face these changes. As mentioned by a number of authors, older people will indicate the direction and trends of the market and in the future, they will belong to key customers. For businesses, it is therefore important to pay attention to this group. Current socio-economy data (Czech Statistical Office, 2014) suggests a more detailed characteristic of the older population, which earns more than 10,000 CZK from the overwhelming majority. This was also demonstrated by the respondents from this study, with almost $90 \%$ of the pension being higher. Old-age pensions are gradually increasing, however, to what extent is the question of the consensus of political garnitures. This is another reason that encourages the attractiveness of this market segment in the future as well.

When focusing on this target group, it is important to prepare not only a good portfolio of products and services but also to create marketing communication campaigns which will effectively target people over 55 years old. This study revealed the most preferred marketing communication tools, such as printed advertising (leaflets, catalogues), sales promotion, and fairs. Generally speaking, these are marketing communication tools where potential customers can find enough written information that they can read and then think about buying. The written form gives the 
customer a higher percentage of assurance about the truthfulness of the information. These are some of the reasons why the older age group most often chooses this option of advertising. The popularity of leaflets in the Czech population is also constantly acknowledged by marketing surveys (Malčikovová, 2012). Other preferred marketing tools are so-called sales promotions. The tools that give the customer some added value or benefits in the form of gifts, discounts, club membership, special benefits, competitions, etc. The third most preferred marketing tool is event marketing in the form of markets or trade fairs, where customers can usually convince themselves about the quality of the product or its function. At the same time, products or services are often provided with a certain advantage or discount in these kinds of events. However, it is necessary to adhere to the ethical aspect of sales during event marketing and not to use unfair practices. These companies are often referred to as the slang "shame" (Wolf, 2017).

This survey also confirmed the growing popularity of fairs and markets in the Czech Republic. This type of marketing tool is perceived in connection with the image of the sale of local producers, quality goods, and small producers. This may also be one of the reasons why event marketing is preferred by this target group. Although nationwide surveys tend to favor TV advertising, this preference has not been proved by this survey. However, what was further confirmed by this research was the indisputable trend of using the Internet (McGaughey \& Mason, 1998). The use of the Internet as a communication tool underlines the importance of this mass media for both people and businesses. And the use of the Internet to communicate with friends and family is also important for people over age 55. Without a doubt, the importance of social networks is exemplified by Papasolomou \& Melathiou (2012). These responses show that current seniors and people aged 55+ are trying to adapt to today's trends. This study highlighted the different preferences of women and men in the choice of marketing tools. A detailed view on printed advertising aspects (background colour, type and size of font, presenting person) suggests an almost consistent view of both genders. The Sans serif is better and easier to read. This is related to the preferences of the greatest possible font size. Companies and organizations should present their products and services in their advertising messages through experts. Celebrities in ads are not positively perceived by respondents $55+$, so businesses should cease hiring them. In case of the colour illustrations, companies should be aware of differences in gender preferences. Women choose more positive and bright colours, while men do not mind even more pronounced colours like dark blue. Most preferred, however, is light green, which is natural and calming.

Comparing the secondary results from the previous study by Barešová \& Staňková (2015), their addressed companies said that they mostly used banner web advertising, printed advertising and outdoor advertising for the promotion of their products and services targeting those age 55+. Their results partly coincide with the newly identified preferences in this study. Companies and organizations appeal to their potential customers through a great number of marketing tools. However, it is still necessary to point out the unplanned space towards this group of customers. Companies should improve their sales promotion activities and generally pay more attention to this target group to gain a competitive advantage, where these customers become one of the key market segments. 
It is necessary to take into account two substantive limits of research - gender differences and location of the research. This study was limited from a geographic point of view, where the vast majority of respondents were from the Zlín Region, and the data obtained cannot be clearly abstracted for the whole Czech Republic. Despite this limiting factor, the Zlín Region is among the regions with the highest number of elderly in the Czech Republic (Benešová and Dědič, 2015). Another limit is the age group, because this group includes a heterogenous group of people from socio-economic characteristics (active and non-active). The final values can be further distorted by the prevalence of women (about $80 \%$ ) to men. National statistics indicate a higher number of elderly women, approximately 60\% to 40\% aged 60+ (Czech Statistical Office, 2016b).

\section{CONCLUSION}

The population aging and a significant increase in the elderly population is not only one of the most currently discussed topics, but it brings a number of challenges not only for companies but also for the public sector. It is not just a local trend, but a global one. At the same time, demographic predictions clearly indicate that this trend will continue to grow. For this reason, this age group will have a significant impact on the market (increasing the competitive advantage) and society (e.g., the social and health systems, the economy, and the public sector of the countries, etc.). Like any age, old age has its own specifics and characteristics. Therefore, one of the key tasks for companies and organizations is to understand the needs of the target group of people over age 55. An important part of organizations' marketing processes will be finding a way to effectively reach this target group through marketing communication tools to create regular and long-term customers. As it is emphasized by Karlíček (2016), Vysekalová (2000), and Přikrylová (2012), the use of suitable marketing tools for both the company and the customer is mutually beneficial. Properly chosen marketing communication tools will help businesses meet their marketing or business goals. At the same time, they can save the money they would spend using other tools that would not effectively reach the target audience.

Within this study, a target group of people age 55+ identified the three most preferred marketing tools including flyers and catalogues, sales promotion, and participation in fair trades, fairs, and markets. These are tools businesses should include in their marketing campaigns when they want to reach the 55+ target group. If companies want to attract only one gender, then women are attracted more through leaflets and catalogues, sales promotions, contests, club membership, gifts to purchase, websites, and finally through fair trades, fairs, and markets. Men are most interested in leaflets and catalogues, advertising on the Internet, and fair trades, fairs, and markets. Printed advertising forms have different aspects (background colour, font size, font size, people in advertising). The respondents are more inclined to these aspects of printed advertising: light green, sapphire font with the largest possible font size (30pt + in titles and 20pt in text content), and even better if the product or service is offered by a specialist in the area. The difference in opinion between men and women is only in the preference of colours, where women prefer colours that are lighter and more positive, such as light green, light blue, and yellow. Despite this, men also like bright colours, but they do not care - even responding well to darker and more 
intense colours like dark blue or yellow. Different is also the time women and men spend reading leaflets. Men read fliers longer than women. They spend up to 30 minutes a week reading them, while women read leaflets for 15 minutes on average. It was evident that both genders spend time on the Internet. Both genders use the Internet mostly to communicate with family and friends, looking for product and service information, and they also like online shopping. If the companies follow the results from this study, they can better understand and attract the target group, so it can increase their competitive advantage.

A great benefit for theory and for practical use was having new ideas about the target group and their views on marketing communication. At the same time, this work highlights the necessity to deal with the issues of ageing and population ageing more deeply and from different perspectives.

\section{References}

1. Accolla, A., \& Garini, F. (2017). The Business Opportunity of Longevity. In International Conference on Applied Human Factors and Ergonomics (pp. 45-59). Springer, Cham. https://doi. org/10.1007/978-3-319-60597-5_5.

2. Ahmad, R. (2002). The older or ageing consumers in the UK: are they really that different?. International Journal of Market Research, 44(3), 337.

3. Barešová, P., \& Staňková, P. (2015). Segment over 55 years old as a new challenge for the Czech companies. In 7th International Scientific Conference on Finance and Performance of Firms in Science, Education and Practice (7 ed., pp. 48-58). Zlín: Tomas Bata University in Zlín, Faculty of Management and Economics.

4. Barešová, P., \& Staňková, P. (2016). Global Challenge: Population Aging and their leisure time. In Globaliáácia a jej sociálno-ekonomické dôsledky (pp. 104-110). Žilina: Žilinská univerzita v Žiline.

5. Beck, B. (1996). The luxury of longer life. Economist, 7-9.

6. Benešová, J., \& Dědič, P. (2015). Senioři v mezikrajském srovnání - část I. Demografie: Revue Pro Výžkum A Populační Vývoj, (58), 85-98.

7. Birkett, H., Carmichael, F., \& Duberley, J. (2017). Activity in the third age: Examining the relationship between careers and retirement experiences. Journal Of Vocational Behavior, 103 (1), 52-65. https://doi.org/10.1016/j.jvb.2017.08.002.

8. Czech Statistical Office (2014). Česká republika od roku 1989 v číslech. Rertrieved June 12, 2017 from: http://www.czso.cz/csu/2014edicniplan.nsf/p/320181-14\#13.

9. Czech Statistical Office (2016a). Veřejná databáze. Retrieved January 8, 2017, from https://vdb.czso.cz/vdbvo2/faces/cs/index.jsf;jsessionid=kfFiBn244FaCCqUhBnHu2 cZPUnvNJL_Vjeckg55rmK2o3balXnbi!-1184700034?page= vystupobjekt\&pvo=DEMD $001 \& \mathrm{z}=\mathrm{T} \& \mathrm{f}=\mathrm{TABULKA} \& \mathrm{katalog}=30845 \& \mathrm{str}={ }_{\mathrm{v}} 4 \& \mathrm{c}=\mathrm{v} 3 \sim 22_{-} \mathrm{RP} 2014 \mathrm{MP} 12 \mathrm{DP} 31 \mathrm{H}_{\mathrm{w}}=$.

10. Czech Statistical Office (2016b). Obyvatelstvo, rodiny a domácnosti. Retrieved May 15, 2017 from https://www.czso.cz/csu/czso/1-obyvatelstvo-a-rodiny-a-domacnosti37ubg89xpz. 
11. Dvořáková, Š. Proč se soustředit na seniory? [Online]. E15. Strategie, 2007. Retrieved from http://strategie.e15.cz/prilohy/marketing-magazin/proc-se-soustredit-naseniory.

12. Dychtwald, K. (c1999). Age power: how the 21st century will be ruled by the new old. New York: Jeremy P. Tarcher/Putnam.

13. Fill, C. (2013). Marketing communications: brands, experiences and participation (Sixth edition.). Harlow: Pearson.

14. Hendl, J., \& Remr, J. (2017). Metody výzkumu a evaluace. Praha: Portál.

15. Karlíček, M. (2016). Marketingová komunikace: jak komunikovat na našem trbu (2., aktualizované a doplněné vydání). Praha: Grada Publishing.

16. Kitchen, P. (2015). New paradigm - IMC - under fire. Competitiveness Review, 15(1), 72-80. https://doi.org/10.1108/cr.2005.15.1.72.

17. Kohlbacher, F., \& Herstatt, C. (c2011). The silver market phenomenon: marketing and innovation in the aging society (2nd ed.). New York: Springer.

18. Kotler, P. (2007). Moderni marketing: 4. evropské vydání. Praha: Grada.

19. Lamberton, C., \& Stephen, A. T. (2016). A Thematic Exploration of Digital, Social Media, and Mobile Marketing: Research Evolution from 2000 to 2015 and an Agenda for Future Inquiry . Journal Of Marketing, 80(6), 146-172. https://doi.org/10.1509/jm.15.0415.

20. Lee, D. H., \& Park, C. W. (2007). Conceptualization and Measurement of Multidimensionality of Integrated Marketing Communications. Journal Of Advertising Research, 47(3), 222-236. https://doi.org/10.2501/S0021849907070274.

21. Long, N. (1998). Broken down by age and sex: Exploring the ways we approach the elderly consumer [Online]. Journal of the Market Research Society, 40(2), 73-91. Retrieved from https://search.proquest.com/openview/5b3af3185e07ea2a7f0738709aa39162/1?pqorigsite $=$ gscholar $\& \mathrm{cbl}=45628$.

22. Luck, E., \& Moffatt, J. (2009). IMC: Has anything really changed? A new perspective on an old definition. Journal Of Marketing Communications, 15(5), 311-325. https://doi. org/10.1080/13527260802481256.

23. Malčikovová, M. (2012). Budoucnost reklamních letáků: bojují s televizí a internetem. [Online]. In E15.c\%. Retrieved from http://media.e15.cz/special/budoucnost-reklamnichletaku-bojuji-s-televizi-a-internetem-744823.

24. Malíková, E. (2011). Péće o seniory v pobytových sociálních [sic] zarízenenich. Praha: Grada.

25. Mankiw, N. G., \& Taylor, M. P. (2014). Macroeconomics (3rd ed.). Andover: Cengage Learning.

26. McGaughey, R. E., \& Mason, K. H. (2015). The Internet as a Marketing Tool. Journal Of Marketing Theory And Practice, 6(3), 1-11. https://doi.org/10.1080/10696679.1998.11501800.

27. MPSV ČR (2013). Životní a existenční minimum [Online]. Retrieved January 8, 2015 from http://www.mpsv.cz/cs/11852.

28. Mühlpachr, P. (2004). Gerontopedagogika. Brno: Masarykova univerzita. 
29. Němečková, M., \& Štyglerová, T. (2014). Projekce obyvatelstva v krajích České republiky do roku 2050. Sociologický Casopis, 50(1), 79-94.

30. Papasolomou, I., \& Melanthiou, Y. (2012). Social Media: Marketing Public Relations' New Best Friend. Journal Of Promotion Management, 18(3), 319-328. https://doi.org/10.1080 /10496491.2012.696458.

31. Patti, C. H., Hartley, S. W., van Dessel, M. M., \& Baack, D. W. (2015). Improving integrated marketing communications practices: A comparison of objectives and results. Journal Of Marketing Communications, 23(4), 351-370. https://doi.org/10.1080/13527266.20 15.1027251 .

32. Polizzi, K. G., \& Millikin, R. J. (2002). Attitudes toward the elderly: Identifying problematic usage of ageist and overextended terminology in research instructions. Educational Gerontology, 28(5), 367-377. https://doi.org/10.1080/03601270290081344.

33. Přikrylová, J., \& Jahodová, H. (2010). Moderni marketingová komunikace. Praha: Grada.

34. Raiko, D. V., Tseytlin, L. M., \& Kyrylenko, V. I. (2017). Developing the classification of non-traditional marketing communication tools. Marketing And Management Of Innovations, 2017 (2), 36-46. https://doi.org/10.21272/mmi.2017.2-03.

35. Sak, P., \& Kolesárová, K. (2012). Sociologie stárí a seniorů. Praha: Grada.

36. Shen, G. C. C., Chiou, J. S., Hsiao, C. H., Wang, C. H., \& Li, H. N. (2016). Effective marketing communication via social networking site: The moderating role of the social tie. Journal of Business Research, 69(6), 2265-2270. https://doi.org/10.1016/ j.jbusres.2015.12.040.

37. Shirkhodaie, M., \& Rastgoo-deylami, M. (2016). Positive Word of Mouth Marketing: Explaining the Roles of Value Congruity and Brand Love. Journal of Competitiveness, 8(1), 19-37. https://doi.org/10.7441/joc.2016.01.02.

38. Schultz, D. E. (1993). Integrated marketing communications: Maybe definition is in the point of view [Online]. Marketing News, 27(2), 17. Retrieved from https://search.proquest. com/docview/216425345?accountid=15518.

39. Sokáčová, L. (2005). Reprezentace seniorů a seniorek v médiích [Online]. In Feminismuscz: Retrieved from http://www.feminismus.cz/cz/clanky/reprezentace-senioru-aseniorek-vmediich-3.

40. Treguer, J. P. (2002). 50+ marketing: marketing, communicating, and selling to the over 50s generations (2002nd ed.). New York: Palgrave.

41. Vysekalová, J., \& Komárková, R. (2001). Psychologie reklamy. Praha: Grada.

42. Wolf, V. (2017). Hromadná žaloba, nový bič na šmejdy. Češi by mohli vymáhat společné odškodnění [Online]. In Lidovky.c\%. Praha: MAFRA. Retrieved from http://www.lidovky. cz/hromadna-zaloba-novy-bic-na-smejdy-cesi-by-mohli-vymahat-spolecne-odskodneni1vm-/noviny.aspx?c=A170611_203311_ln_noviny_ELE. 


\section{Contact information}

Ing. Petra Barešová, BA(Hons), MSc.

Tomas Bata University in Zlin

Faculty of Management and Economics

Mostni 5139, 76001 Zlín

Czech Republic

Email:baresova@utb.cr.

Ing. Monika Horáková, Ph.D.

Tomas Bata University in Zlin

Faculty of Management and Economics

Mostni 5139, 76001 Zlin

Czech Republic

Email:mborakova@utb.cz.

Ing. Tomás Urbánek

Tomas Bata University in Zlin

Faculty of Management and Economics

Mostni 5139, 76001 Zlin

Czech Republic

Email:turbanek@utb.cz. 